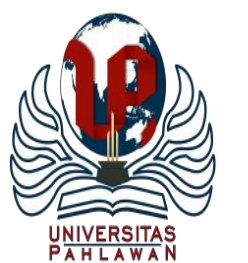

Edukatif : Jurnal Ilmu Pendidikan Volume 3 Nomor 3 Tahun 2021 Halm 640 - 648 EDUKATIF: JURNAL ILMU PENDIDIKAN

Research \& Learning in Education

https://edukatif.org/index.php/edukatif/index

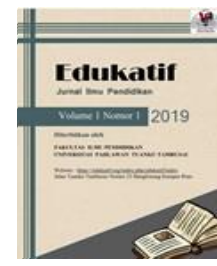

\title{
Pengembangan Instrumen Penilaian Sikap Gotong Royong dalam Pembelajaran Tematik di Sekolah Dasar
}

\author{
Dian Kurniawati ${ }^{1 凶}$, Mawardi $^{2}$ \\ Universitas Kristen Satya Wacana, Indonesia ${ }^{1,2}$ \\ E-mail : diankurniawati615@gmail.com ${ }^{1}, \underline{\text { mawardi@ @staff.uksw.edu }}^{2}$
}

\begin{abstract}
Abstrak
Studi pendahuluan tentang penilaian di sekolah dasar menemukan bahwa praktik penilaian ranah sikap masih didominasi dengan penggunaan instrumen lembar pengamatan untuk menilai perilaku siswa, padahal hakikat sikap berbeda dengan perilaku. Penelitian ini bertujuan untuk mengembangkan instrumen penilaian sikap, khusunya gotong royong untuk siswa kelas 3 sekolah dasar menggunakan Skala Likert. Penelitian ini menggunakan jenis peneltian dan pengembangan $(R \& D)$, penelitian ini menggunakan instrumen berupa rubrik penilaian uji ahli. Penelitian instrumen penilaian sikap gotong royong berbentuk Skala Likert dengan empat opsi, telah dilakukan uji tingkat validitasnya oleh ahli. Penelitian pengembangan ini telah menghasilkan produk instrumen penilaian sikap gotong royong dalam pembelajaran tematik kelas 3 sekolah dasar. Produk tersebut telah dilakukan validasi kepada ahli Hasil dari uji validasi ahli, diperoleh skor dari ahli desain pembelajaran sebesar 93,6\% berada dalam kategori sangat tinggi. Hasil uji ahli bahasa mendapatkan $88,3 \%$, maka menunjukkan kategori sangat tinggi. Hasil uji ahli penilaian sikap mendapatkan skor $77,1 \%$, berada dalam kategori tinggi. Berdasarkan uji validitas ahli desain pembelajaran, ahli bahasa dan ahli peniaian ranah sikap, berada kategori tinggi dan sangat tinggi, maka instrumen penilaian sikap gotong royong layak untuk digunakan. Instrumen penilaian sikap ini dapat dimanfaatkan guru untuk menilai sikap gotong royong siswa pada pembelajaran tematik kelas 3 sekolah dasar.
\end{abstract}

Kata Kunci: instrumen penilaian sikap, gotong royong, pengembangan

\begin{abstract}
A preliminary study on assessment in primary schools found that the practice of assessing the domain of attitudes was still dominated by the use of observation sheet instruments to assess students' behavior, even though the nature of attitudes was different from behavior. This study aims to develop an attitude assessment instrument, especially mutual cooperation for grade 3 elementary school students using a Likert scale. This research is a research and development $(R \& D)$ type, this study uses an instrument in the form of expert test assessment rubric. Research on mutual cooperation attitude assessment instruments in the form of a Likert scale with four options, has been tested for its validity level by experts. This development research has resulted in the product of an assessment instrument for mutual cooperation in the thematic learning of grade 3 elementary schools. The product has been validated by the expert. The results of the expert validation test showed that the score of the learning design expert was $93.6 \%$ in the very high category. The result of the linguist's test got $88.3 \%$, it means that the category is very high. The results of the attitude assessment expert test got a score of $77.1 \%$, which is in the high category. Based on the validity test of learning design experts, linguists and attitudes assessment experts, in the high and very high categories, the mutual assistance attitude assessment instrument is feasible to use. This attitude assessment instrument can be used by the teacher to assess the attitude of mutual cooperation of students in grade 3 thematic learning in elementary schools.

Keywords: attitude assessment instrument, mutual cooperation, development
\end{abstract}

Copyright (c) 2021 Dian Kurniawati, Mawardi

$\square$ Corresponding author

Email : diankurniawati615@gmail.com

DOI $\quad$ : https://doi.org/10.31004/edukatif.v3i3.387

ISSN 2656-8063 (Media Cetak)

ISSN 2656-8071 (Media Online)

Edukatif : Jurnal Ilmu Pendidikan Vol 3 No 3 Tahun 2021 p-ISSN 2656-8063 e-ISSN 2656-8071 


\section{Pengembangan Instrumen Penilaian Sikap Gotong Royong dalam Pembelajaran Tematik di Sekolah Dasar - Dian Kurniawati, Mawardi \\ DOI: https://doi.org/10.31004/edukatif.v3i3.387}

\section{PENDAHULUAN}

Karakter dan ciri khas dari setiap individu masing-masing berbeda. Demikian juga, suatu bangsa di setiap negara memiliki karakter bangsa yang menjadi jati diri setiap warganya. Karakter bangsa memiliki peran penting untuk perkembangan suatu bangsanya. Maka pendidikan karakter di setiap satuan pendidikan. Sebenarnya pemerintah sudah mengembangkan pendidikan karakter, khususnya dalam pembelajaran.Hal ini tampak dalam UU 20 tahun 2003 terkait dengan Sistem Pendidikan Nasional pada pasal 3 yaitu: "pendidikan nasional berfungsi mengembangkan kemampuan dan membentuk watak serta peradaban bangsa yang bermartabat dalam rangka mencerdaskan kehidupan bangsa, bertujuan untuk berkembangnya potensi peserta didik agar menjadi manusia yang beriman dan bertaqwa kepada Tuhan Yang Maha Esa, berakhlak mulia, sehat, berilmu, cakap, kreatif, mandiri,dan menjadi warga Negara yang demokratis dan bertanggungjawab."

Pembelajaran tematik digunakan di sekolah dasar pada kurikukulum 2013. Pembelajaran tematik adalah mengaitkan pada berbagai mata pelajaran dimuat dalam sesuatu tema(Wahyuni et al., 2016). Pada kurikulum 2013 mempunyai 5 komponen, yaitu materi, metode / model /, strategi pembelajaran, media pembelajara, serta penilaian. B erfokus pada kompinen penilaian pembelajaran mengacu pada Undang-undang nomor 23 tahun 2016 terkait Standar Penilaian Pendidikan. Penilaian merupakan proses yang sistematis untuk mengetahui sejauhmana peserta didik dalam mencapai tujuan pembelajaran (Umami, 2018). Untuk melakukan penilaian terhadap siswa tentunya harus menggunakan instrumen penilaian yang tepat dan sesuai. Pada Permendikbud nomor 23 tahun 2016 pasal 16 menyatakan instrumen penilaian yang digunakan harus memenuhi persyaratan konstruksi, substansi, dan mempunyai bukti validitas yang empirik. Pada instrumen penilaian tersebut perlu dianalisis sebelum dan sesudah digunakan agar dapat menghasilkan instrumen penilaian yang layak digunakan.

Penelitian pengembangan ini berfokus pada ranah afektif / sikap. Sikap pada seseorang merupakan suatu respon atau reaksi dari seseorang seseorang pada suatu objek (Mulyanti \& Fachrurrozi, 2017). Memiliki sikap gotong royong tentu sikap yang baik tehadap sesama. Gotong royong sebagai kegiatan atau tindakan yang dilakukan bersama-sama secara suka rela atau tidak meminta imbalan untuk tujuan bersama(Ali \& Palimbong, 2019) . Gotong royong sebagai bentuk dari solidaritas sosial, solidaritas soaial muncul karena terdapat bantuan dari pihak lain untuk kepentingan individu maupun bersama yang bersikap loyal dalam satu kesatuan.

Berdasarkan hasil observasi di SDN 1 Kedungjati, SDN 2 Kedungjati, dan SDN 3 Kedungjati memperoleh informasi bahwa di kelas 3 dalam pembelajaran pengetahuan guru telah melakukan penilaian terhadap peeserta didik. Akan tetapi, guru jarang melakukan penilaian sikap yang sesuai dengan kurikulum 2013. Misalnnya dalam buku tematik terdapat instrumen penilaian sikap, tetapi pada saat itu guru hanya menilai berdasarkan penilaian pengetahuan. Guru juga jarang melakukan pengembangan sendiri terhadap penilaian sikap kepada peserta didiknya. Guru kelas biasanya menilai peserta didiknya dalam pengamatan pada waktu di sekolah, tidak menggunakan instrumen penilaian tertentu yang dibuat untuk menilai peserta didiknya. Guru juga tidak menyediakan instrumen penilaian sikap, seperti sikap gotong royong, bertanggung jawab maupun toleransi. Guru kelas melakukan penilaian sikap seperti sikap gotong royong hanya beberapa kali saja dalam satu subtema. Penilaian seperti ini menyebabkan guru kurang memahami karakter siswa. Sehingga akan berdampak pada sikap peserta didik misalnya pada gotong royong, karena guru kurang memahami karakteristik peserta didik secara berlanjut, sikap peserta didik jadi tidak teridentifikasi oleh guru. Misalnya jika ternyata siswa A tidak selalu bersikap gotong royong. Atau siswa yang pemalu, pendiam sungkan berinteraksi justru memiliki sikap yang gotong royong namun tidak teridentifikasi oleh guru. Tampak bahwa belum ditemukan instrumen penilaian sikap gotong royong yang baik dan sesuai dengan pembelajaran tematik SD kelas 3. Guru belum melakuakan penelitian pada setiap pembelajaran yang ada kaitannya dengan 
nilai kegotongroyongan. Guru belum pernah mengembangkan instrumen penilaian dan diujikan kepada peserta didik.

Penelitan relevan lainnya dilakukan oleh (Syihabuddin et al., 2018) yang menjelaskan pada hasil observasi dan wawancaranya kurangnya pemahan guru terkait penilaian sikap pada kurikulum 2013, menurut guru terdapat banyak bentuk instrumen penilaian untuk menilai sikap siswa. Guru hanya melaksanakan penilaian observasi sehingga instrumen penilaiannya terabaikan karena kurang pahamnya terkait penilaian sikap yang sesuai. Guru juga masih kurang paham terkait kriteria-kriteria yang terdapat pada instrumen penilaian sikap. Penelitian pengembangan juga dilakukan oleh (KUSUMAWATI, 2015) menjelaskan guru harus mampu melakukan penelitian pada ranah afektif. Perlu dilakukannya pengukuran nilai pada ranah afektif dengan menggunakan instrumen penilaian yang tepat sehingga nilai afektif yang didapatkan siswa lebih akurat. Penelitian yang dilakukan oleh (Hajaroh \& Adawiyah, 2018) dapat ditarik kesimpulan bahwa guru menyebutkan jika pelatihan dari dinas pendidikan terkait penilaian masih kurang. Biasanya guru bertanya kepada sesama rekan dan rata-rata rekan sejawat, terkada belajar mencari tau sendiri maupun otodidak. Karena guru kesulitan pengembangan penilaian siswa guru juga kesusahan untuk upaya apa yang dilakukan untuk mengatasi setiap sikap yang kurang sesuai pada siswa. Selanjutnya penelitian dilakukan oleh (Riscaputantri \& Wening, 2018) guru jarang melaksanakan penilaian afektif seringnya melakukan penlaian kognitif karena guru belum mngetahu cara-cara penilaian pada ranah afektif. Seringnya hanya melakukan komponen observasi kepada siswa. Oleh sebab itu dilakukan pengembangan instrumen penilaian sikap kepada siswa, dan telah dilakukan uji realibilitas dan validitas sehingga instrumen penilainnya layak untuk digunakan. Pada penelitian yang dilakukan oleh (Sriyono, 2019) melakukan pengembangan terkait instrumen pada penilaian sikap sosial, penilaian sikap sosial guru pada pembelajaran fisika di SMP masih terbatas, perlu dilakukannya cara agar siswa terlibat di dalamnya, maka dilakukan pengembangan instrumen penialian sikap sosial. Memberikan efek yang baik kepada siswa, selain siswa dapat terlibat langsung, guru juga dapat mengetahui sejauhmana sikap yang dimiliki oleh siswa dan hasilnya valid untuk digunakan. Penelitian juga dilakukan oleh (Dessiane \& Kristin, 2021) saat melaukan survei lapangan di sekolah dasar disimpulkan bahwa jika di SD tidak ditemukannya penilaian instrumen penilaian sikap sosial yag akurat. Oleh sebab itu ia mengembangkan instrumen penilaian sikap sosial menggunakan skala likert dengan 30 pernyataan yang diuji kelayakannya dengan melakukan validasi ahli dengan hasil 80\% maka dengan kategori tinggi. Dapat diambil kesimpulan bahwa instrumen penilaian layak untuk digunakan, dimanfaat sebagai penilaian sikap sosial oleh guru kepada siswa. Kemudian penelitian dilakukan oleh (Safitri \& Harjono, 2021) guru sudah melakukan penilaian aspek sikap, tetapi hanya menggunakan pada rubrik penilaian yang dimuat dalam buku guru kurikulum 2013. Juga belum ditemukan terdapat instrumen penilaian ranahah sikap yang telah dikembangkan maupun diuji kelaykannya oleh ahli. Pada penelitiannya dilakukan pengembangan instrumen penilaian pada ranah sikap. Melalui uji validasi kepada 3 ahli ahli menunjukkan skor $80 \%$ ahli penilaian, $86 \%$ ahli materi, dan 95\% ahli bahasa. Dapat disimpulkan bahwa pengembangan instrumen penilaian sikapnya dapat dimanfaatkan untuk guru menilai sikap siswa.

Melihat pada beberapa kasus dan penelitian yang ada dapat disimpulkan perulunya memahami penilaian sikap yang sesuai dan akurat. Oleh sebab itu penelitian ini dilakukan untuk melakukan pengembangan terhadap instrumen penilaian sikap sosial, khussnya gotong royong terhadap siswa pada sekolah dasar. Maka akan dapat digunakan sebagai alat penilaian sikap kepada siswa. Selain itu juga dapat membantu mengembangkan sikap gotong royong yang dimiliki siswa.

\section{METODE PENELITIAN}

Terdapat macam-macam jenis penelitian, salah satunya adalah Research and Development (R\&D yang biasa disebut dnegan penelitin pengembangan. Peneliti menggunakan jenis peneletian dan pengembangan ini. Tujuan penelitian dan pengembangan untuk mengembangkan suatu produk, menyempurnakan produk, atau 
menghasilkan produk dan bisa dipertanggungjawabkan (Sukmadinata, 2016, p. 164). Ruang lingkup instrumen pada penelitian dan pengmbangan ini yaitu pengembangan instrumen penilaian sikap gotong royong di kelas 3 SD pada tema 8 "Praja Muda Karana", subtema ke-2 “Aku anak Mandiri", pembelajran 5. Instrumen penilaian sikap gotong royong yang dikembangkan berupa butir pernyataan dengan Skala Likert dengan empat opsi (SS =Sangat Setuju; S = Setuju; TS = Tidak Setuju; dan STS = Sangat Tidak Setuju), dengan jumlah 30 pernyataan. Pada penelitian pengebangan ini, produk akhir yang dihasilakan mencakup indikator dan kisi-kisi butir pernyataan.

Pada penelitian pengembangan ini, langkah-langkah yang digunakan ialah langka-langkah dari Sukmadinata yang membagi pada 3 tahapan yaitu terdapat studi pendahuluan, selanjutnya melakukan pengembangan, dan melakkan pengujian. Pada tahap studi pendahuluan pada penelitian pengembangan adalah tahap pendefinisian. Ada dua langkah yaitu melalui studi kepustakaan dan melakukan survey lapangan. Pada tahap pengembangan menggunakan model Instructional Design melalui pendekatan ADDIE (Analysis, Design, Development, Implementation, dan Evaluation) (Sugiyono, 2009, p. 432). Instrumen yang digunakan adalah rubrik penilaian ahli desain pembelajaran, ahli bahasa dan ahli penilaian ranah sikap. Teknik analisis data menggunakan persentase dan kategoris. Data diperoleh berdasarkan hasil dari uji validasi kepada 3 ahli terdapat ahli pada aspek desain pembelajaran, selanjutnya ahli pada aspek bahasa, serta ahli pada aspek penilaian ranah sikap.

\section{HASIL DAN PEMBAHASAN}

Peneliti menggunakan langkah-langkah dari Sukmadinata untuk melakukan penelitian pengembangan instrumen penilaian sikap gotong royong ini, serta menggunakan model pengembangan ADDIE, terdapat 3 langkah yaitu : (1) Studi Pendahuluan; (2) Pengembangan; (3) Pengujian.

Pada langkah studi pendahuluan merupakan langkah pertama dalam melakukan penelitian (R\&D). Pada langkah ini ada 2 tahapan yang dilakukan yaitu melalui studi kepustakaan serta melakukan survei lapangan. Pada tahap studi kepustakaan telah dihasilkan suatu bahan dasar yaitu sikap gotong royong. Bahan dasar dari studi kepustakaan ini akan digunakan sebagai penyusunan produk instrumen penilaian pada aspek sosial sikap gotong royong. Tahapan pada survei lapangan ditemukan jika guru masih kurang memperhatikan terkait penilaian sikap yang dilakukan terhadap siswa. Guru cenderung menilai sikap siswa dengan pengamatan saja yang akhirnya terkesan penilaian yang dilakukan tidak obyektif.

Pada langkah pengembangan telah dilakukannya observasi dan wawancara di SDN 1 Kedungjati, SDN 2 Kedungjati, dan SDN 3 Kedungjati di kecamatan Kedungjati, kabupaten Grobogan. Dari hasil observasi dan wawancara menunjukkan jika yang terjadi selama ini terkesan tidak adanya penilaian yang obyektif yang dilakukan oleh guru terhadap siswa kelas 3 sekolah dasar terkait penilaian sikap gotong royong pada pembelajaran tematik. Pada analisis kebutuhan peneliti memilih untuk mengembangkan sebuah prouk yaitu instrumen penilaian sikap gotong royong dalam pembelajaran tematik, kelas 3 pada Tema 8 "Praja Muda Karana”, subtema2 "Aku anak Mandiri". Selanjutnya melakukan perancangan draft produk berdasarkan tema yang akan diambil yaitu Tema 8 "Praja Muda Karana", subtema2 "Aku anak Mandiri" pembelajaran 5. Peneliti telaah memilih tema tersebut karena sesuai dengan aspek penialian yang akan dikembangkan. Selanjutnya menentukan kompetensi inti, pada penelitian ini peneliti fokus pada pengembangan instrumen penilaian yaitu ins trumen penilaian sikap sosial yang terdapat pada (KI-2). Setelah menentukan tema (KI), maka menentukan (KD), kompetensi dasar yang digunakan adalah (KD-2) yang akan dikembangkan menjadi indikator yang akan dicapai. Setelah menentukan indikator langkah selanjutnya membuat RPP dengan desain yang inovatif. Kemudian menyusun kisi-kisi pengukuran sikap gotong royong. Pada tabel 1 adalah kisi-kisi yang dihasilkan untuk melakukan penilaian sikap gotong royong kelas 3 dengan objek "Gotong Royong": 
644 Pengembangan Instrumen Penilaian Sikap Gotong Royong dalam Pembelajaran Tematik di Sekolah Dasar - Dian Kurniawati, Mawardi

DOI: https://doi.org/10.31004/edukatif.v3i3.387

Tabel 1 Kisi-kisi Instrumen Penilaian Sikap Gotong Royong

\begin{tabular}{|c|l|l|l|l|l|}
\hline \multirow{2}{*}{$\begin{array}{c}\text { Indikator penilaian ranah } \\
\text { sikap }\end{array}$} & \multicolumn{3}{|c|}{ Komponen sikap } & \multirow{2}{*}{ Jumlah } & \multirow{2}{*}{} \\
\cline { 2 - 6 } & Kognisi & Afeksi & Konasi & & $10 \%$ \\
\hline Hakikat gotong royong & 2 & & 2 & 4 & $14 \%$ \\
\hline Kerja sama & & 2 & 2 & 4 & $20 \%$ \\
\hline Tujuan bersama & 2 & 2 & 2 & 6 & $16 \%$ \\
\hline Solidaritas sosial & & 2 & 2 & 4 & $20 \%$ \\
\hline $\begin{array}{c}\text { Melakukan tindakan dengan } \\
\text { suka rela }\end{array}$ & 2 & 4 & 2 & 6 & $20 \%$ \\
\hline Jumlah & $\mathbf{6}$ & $\mathbf{1 2}$ & 2 & 6 & $\mathbf{1 0 0 \%}$ \\
\hline
\end{tabular}

Berdasarkan kisi-kisi yang dihasilkan maka dilakukan pembuatan (Instrumen penilaian sikap gotong royong) yang berupa butir-butir pernyataan yang digunakan untuk menilai sikap gotong royong dalam bentuk skala Likert. Dalam pembuatannya menentukan objek sikapnya, apa saja batasannya, tujuannya, dan indikatornya. Terapat 30 butir pernyataan sebagai penilaian terhadap sikap siswa memiliki pernyataan berjumlah 6 kognisi, 12 afeksi, dan 12 berupa pernyataan konasi. Setelah membuat 30 pernyataan dilakukan uji kelayakan. Peneliti melakukan uji kelayakan terhadap 3 ahli, terdapat ahli pada aspek desain pembelajaran, apek penilaian, dan aspek bahasa. Hasil uji kelakayan dan pembahasaanya dapat dilihat pada tabel 2, tabel, 3, dann 4.

Tabel 2 Hasil Validasi Aspek Desain Pembelajaran

\begin{tabular}{|l|c|c|c|c|}
\hline \multicolumn{1}{|c|}{ Aspek } & Skor Ideal & Skor Aktual & $\begin{array}{c}\text { Presentase } \\
\text { Kelayakan }\end{array}$ & Kategori \\
\hline Komponen & 65 & 60 & $92,3 \%$ & Sangat Tinggi \\
\hline Prinsip & 20 & 19 & $95 \%$ & Sangat Tinggi \\
\hline $\begin{array}{l}\text { Rata-rata hasil uji validasi aspek desain } \\
\text { pembelajaran }\end{array}$ & $\mathbf{9 3 , 6 \%}$ & Sangat Tinggi \\
\hline
\end{tabular}

Dapat dilihat tabel 1 adalah hasil validasi oleh ahli pada aspek desain pembelajaran sikap gotong royong dalam pembelajaran tematik kelas 3. Validasi desain pembelajaran didasarkan pada Permendikbud No. 22 tahun 2016 yang terdapat 2 aspek yaitu aspek komponen pembelajaran, serta prinsip pembelajaran. Berdasarkan pada hasil dari validasi oleh ahli desain pembelajaran memperoleh skor 93,6\%. Hasil perolehan skor menunjukkan pada interval 81-100\%, maka termasuk dalam kategori "Sangat Tinggi", maka dapat disimpulkan validasi desain pembelajaran layak untuk digunakan.

Tabel 3 Hasil Uji Validasi Aspek Bahasa

\begin{tabular}{|l|c|c|c|c|}
\hline Aspek & $\begin{array}{c}\text { Skor } \\
\text { Ideal }\end{array}$ & $\begin{array}{c}\text { Skor } \\
\text { Aktual }\end{array}$ & $\begin{array}{c}\text { Presentase } \\
\text { Kelayakan }\end{array}$ & Kategori \\
\hline Lugas & 15 & 15 & $100 \%$ & Sangat Tinggi \\
\hline Komunikatif & 5 & 4 & $80 \%$ & Sangat Tinggi \\
\hline Dialogis dan interaktif & 5 & 4 & $80 \%$ & Sangat Tinggi \\
\hline $\begin{array}{l}\text { Kesesuaian dengan perkembangan } \\
\text { siswa }\end{array}$ & 10 & 8 & $80 \%$ & Sangat Tinggi \\
\hline $\begin{array}{l}\text { Kesesuaian dengan kaidah Bahasa } \\
\text { Indonesia }\end{array}$ & 10 & 10 & $100 \%$ & Sangat Tinggi \\
\hline $\begin{array}{l}\text { Penggunaan istilah, simbol, dan } \\
\text { ikon }\end{array}$ & 10 & 9 & $90 \%$ & Sangat Tinggi \\
\hline Rata-rata hasil uji validasi aspek bahasa & & $\mathbf{8 8 , 3 \%}$ & Sangat Tinggi \\
\hline
\end{tabular}


Dapat dilihat di atas merupakan hasil dari validasi oleh ahli pada aspek bahasa sikap gotong royong pada pembelajaran tematik kelas 3. Validasi aspek bahasa didasarkan pada kriteria kelayakan oleh (Purnanto \& Mustadi, 2018) adalah menggunakan bahasa yang lugas, bahasa komunikatif, bahasa yang dialogi / interaktif, bahasanya sesuai perkembangan siswa, menggunakan kaidah bahasa indonesia yang benar, dan menggunakan istilah dan simbol yang sesuai. Berdasarkan hasil pada validasi ahli bahasa memperoleh skor 88,3\%. Hasiilnya menunjukkan pada interval $81-100 \%$, maka termasuk dalam kategori "Sangat Tinggi", maka hasi daril validasi bahasa dapat disimpulkan "Layak digunakan dengan perbaikan". Peneliti sudah melakukan perbaikan produk berdasarkan saran ahli bahasa pada butir pernyataan nomor 2 kalimatnya untuk dibuat kalimat lebih jelas sehingga produk sudah layak digunakan.

Tabel 4 Hasil Uji Validasi Aspek Penilaian Sikap

\begin{tabular}{|c|c|c|c|c|}
\hline Aspek & Skor Ideal & Skor Aktual & $\begin{array}{c}\text { Presentase } \\
\text { Kelayakan }\end{array}$ & Kategori \\
\hline Kriteria penilaian & 70 & 54 & $77,1 \%$ & Tinggi \\
\hline \multicolumn{2}{|l|}{ Rata-rata hasil uji validasi aspek penilaian sikap } & $\mathbf{7 7 , 1 \%}$ & Tinggi \\
\hline
\end{tabular}

Dapat dilihat di atas merupakan hasil dari validasi terhadap ahli pada aspek penilaian sikap gotong royong pembelajaran tematik kelas 3 sekolah dasar. Validasi aspek penilaian sikap terdapat empat belas kriteria penilaian, seperti pernyataan yang dibuat tidak mengandung unsur masa lalu, tidak mengandung unsur fakta, penafsirannnya tidak lebih dari satu, sesuai dengan objek yang akan diukur, semua pernyataannya tidak mengandung reaksi setuju, pernyataan yang dipilih terkait ranah afektif yang diukur, bahasa yang digunakan langsung, jelas serta sederhana, bahasa yang digunakan ringkas tidak melebihi 20 kata, tidak melebihi 1 gagasan, tidak terdapat unsur universal pada pernyataannya, tidak terdapat kata seperti kata semata-mata, hanya, sekedar dan yang lainnya, penyusunan kata-katanya sederhana, pemahaman kata-katanya tidak sulit, dan kata-katanya tidak mengandung pernyataan yang negatif ganda (Mawardi, 2013). Berdasarkan hasil dari validasi ahli penilaian pada aspek sikap memperoleh skor $77,1 \%$. Hasil perolehan skor tersebut menunjukkan pada interval 61-81\%, maka termasuk dalam kategori "Tinggi", maka hasil uji validasi dari ahli penilaian sikap dapat disimpulkan "Layak digunakan dengan perbaikan". Peneliti telah melakukan perbaikan, maka produk sudah layak untuk digunakan.

Setelah melakukan validasi terhadap 3 ahli, peneliti seharusnya melaksanakan pengujian terbatas maupun uji luas di sekolah dasar. Peneliti juga seharusnya melakukan diskusi kepada guru di sekolah dasar terkait produk yang dibuat, akan tetapi karena sedang terjadi Pandemi Covid-19 pelaksanaan uji terbatas dan uji luas tidak dapat dilaksanakan oleh peneliti karena melalui beberapa pertimbangan salah satunya terkait dengan kesehatan dan keselamatan, serta di kabupaten Grobogan sekolah dasar masih diberlakukannya belajar dari rumah (BDR) berdasarkan himbauan dari pemerintah.

Untuk menyempurnakannya produk instrumen penilaian sikap gotong royong kelas 3 SD dilakukannya evaluasi, evaluasi setelah mendapatkan umpan balik dari ahli. Peneliti melakukan perbaiakan untuk menghasilkan produk instruumen penilaian sikap gotong royong yang baik. Terdapat masukan untuk perbaikan, masukan dari ahli penilaian yaitu untuk kalimatnya dapat disederhanakan lagi, seperti pada pernyataan nomor 4 "Saya jarang menolong orang yang mengalami kesulitan karena saya tidak dapat memberikan solusi" kemudian diperbaiki disederhanakan lagi kalimatnya menjadi "Saya jarang menolong orang yang megalami kesulitan". Selain itu terdapat masukan perbaikan dari ahli bahasa yaitu pada pernyataan nomor 2 kurang jelas pernyataannya "Seharusnya saya melakukan piket kelas agar saat belajar di kelas nyaman" pernyataannya dilakukan perbaikan agar hubungan dari pernyataan tersebut jelas karena piket kelas berhubungan dengan kebersihan sehingga diubah "Seharusnya saya melakukan piket kelas agar kelas menjadi bersih".

Setelah melakukan langkah studi pendahuluan dan pengembangan Untuk mengenalisis statistik pada uji perbedaan pada langkah ini seharusnya dilaksanakan, terdapat pengujian pre test serta post test. Akan tetapi 
yang terjadi pada saat ini masih pada situasi yang sedang terjadi Pandemi Covid-19 sehingga pengujian ini tidak dapat dilakukan. Akan tetapi, pada penelitian pengembangan telah menghasilkan suatu produk instrumen penilakan sikap gotong royong pada pembelajaran tematik di kelas 3 SD. Produk ini dapat digunakan untuk dimanfaatkan sebagai penilaian sikap sosial (gotong royong) kepada siswa. Produk ini mengembangkan dari penilaian sikap yang dilakukan oleh guru kepada siswa yang biasanya hanya mengunakan penilaian berdasarkan pengamatan yang subektif sehingga hasil penilaiannya tidak akurat dan tidak teruji kelayakannya. Oleh sebab itu perlu dilakukannya pengembangan terhadap penilaian sikap siswa. Pada hasil penelitian ini peneliti telah mengembangkan instrumen penilaian sikap gotong royong yang sudah divalidasi oleh 3 ahli dan mendapatkan hasil yang layak digunakan. Maka Instrumen penilaian sikap gotong royong menggunakan skala likert yang telah dikembangkan oleh peneliti dapat dimanfaatkan oleh guru-guru di sekolah dasar sebagai penilaian sikap gotong royong untuk siswa kelas 3 pada Tema 8 "Praja Muda Karana", subtema2 "Aku anak Mandiri", pemebelajaran 5. Penelian pengembangan yang dilakukan penelitian ini mempunyai kelebihan dalam menghasilkan produk instrumen penilaian sikap, karena jika dibandingkan dengan penelitian (Bambang, 2020) dalam menghasilkan produk instrumen penilaian sikap berupa 30 butir pernyataan tidak dilakukan uji kelayakan kepada ahli, seharusnya perlu dilakukan proses validasi kepada ahli untuk mengetahui apakah instrumen yang dihasilkan layak untuk digunakan atau tidak. Penelitian peneliti juga lebih baik dari penelitian (Candra et al., 2018) karena instrumen penilaian sikap menggunakan skala likert yang dihasilkan hanya terdapat 3 opsi, sedangkan peneliti menggunakan 4 opsi sehingga lebih bervariasi dan sesuai dengan berbagai macam respon dari siswa berdasarkan butir pernyataan yang dipilihnya. Kekurangan pada penelitian ini seharusnya dilakukan uji luas dan uji lapangan yang seharusnya dilakukan, akan tetapi yang terjadi pada saat ini masih pada situasi yang sedang terjadi Pandemi Covid-19 sehingga pengujian ini tidak dapat dilakukan. Covid-19 merupakan penyakit menular yang disebabkan oleh sindrom pernapasan akut coronavirus 2, virus ini ketika menyerang manusia biasanya menyebabkan penyakit infeksi saluran pernapasan, seperti flu, MERS (Middle East Respiratory Syndrome), dan SARS (Severe Acute Rapiratory Syndrome) (Setiawan, 2020).

\section{KESIMPULAN}

Produk yang dihasilkan pada penelitian ini adalah instrumen yaitu intrumen terkait sikap dalam bentuk Skala Likert. Produk yang dihasilkan ini guru dapat menggunakannya untuk melakukan penilaian sikap gotong royong untuk siswa kelas 3 pada Tema 8 "Praja Muda Karana", subtema2 "Aku anak Mandiri". Simpulan ini dapat diambil didasarkan perolehan skor yang menunjukkan perolehan skor pada aspek desain pembelajaran memperoleh skor $93,6 \%$; aspek bahasa dengan perolehan skor $88,3 \%$; dan aspek penilaian sikap memperoleh skor $77,1 \%$.

\section{UCAPAN TERIMA KASIH}

Pada penelitian yang telah dilakukan membutuhkan arahan dan bimbingan dar Bapak Mawardu sebagi dosen pembimbing, maka peneliti mengucapkan terima kasih sehingga penelitian peneliti ini mampu dilaksanakan dengan baik. 
647 Pengembangan Instrumen Penilaian Sikap Gotong Royong dalam Pembelajaran Tematik di Sekolah Dasar - Dian Kurniawati, Mawardi

DOI: https://doi.org/10.31004/edukatif.v3i3.387

\section{DAFTAR PUSTAKA}

Aprilia, N., \& Susilo, M. J. (2014). Pengembangan Instrumen Evaluasi Pembelajaran Microteaching Berbasis Perspekti Keterampilan Dasar Mengajar. Jurnal Bioedukatika, 2(2), 9 https://doi.org/10.26555/bioedukatika.v2i2.4121

Candra, I., Sulistya, N., \& Prasetyo, T. (2018). Pengembangan Instrumen Sikap Sosial Tematik Siswa SD Kelas IV. Jurnal Ilmiah Sekolah Dasar. https://doi.org/10.23887/jisd.v2i4.16167

Dessiane, S. T., \& Kristin, F. (2021). PENGEMBANGAN INSTRUMEN PENILAIAN SIKAP SOSIALPEMBELAJARAN TEMATIK KELAS 4 SD. 6, 21-26.

Fathoni. (2011). Metodologi Penelitian \& Teknik Penyusunan Skripsi. Rineka Cipta.

Hardiani, I. N. (2017). Pengembangan instrumen penilaian sikap sosial pembelajaran IPS kelas IV SD. EJournal Mitra Pendidikan.

Hombing, W. (2015). Peningkatan Pengetahuan, Sikap dan Tindakan Remaja Laki-laki di SMK Negeri 4 Kecamatan Umbulharjo Kota Yogyakarta Tentang Antibiotika Dengan Metode CBIA (Cara Belajar Insan Aktif). Fakl Farmasi;, 2(6), 26. https://repository.usd.ac.id/1708/2/118114134_full.pdf

Kuntoro, B. T., \& Wardani, N. S. (2020). Pengembangan Instrumen Penilaian Sikap Sosial Pembelajaran Tematik Kelas III SD. Jurnal Ilmiah Wahana Pendidikan Https://Jurnal.Unibrah.Ac.Id/Index.Php/JIWP.

Kusumawati, T. (2015). Pengembangan Instrumen Penilaian Ranah Afektif Mata Pelajaran Aqidah Akhlak. Smart, 1(1), 111-123. https://doi.org/10.18784/smart.v1i1.233

Mawardi, M. (2019). Rambu-rambu Penyusunan Skala Sikap Model Likert untuk Mengukur Sikap Siswa. Scholaria: Jurnal Pendidikan Dan Kebudayaan, 9(3), 292-304. https://doi.org/10.24246/j.js.2019.v9.i3.p292-304

Nahrowi, M. (2019). Pengembangan Model Penilaian Autentik dalam Pembelajaran Tematik Berbasis Higher Order Thinking Skill (HOTS) pada Madrasah Ibtidaiyah di Kecamatan Gebog Kabupaten Kudus. ELEMENTARY: Islamic Teacher Journal, 7(2), 279. https://doi.org/10.21043/elementary.v7i2.6005

Novitasari, L., \& Wardani, N. S. (2020). PENGEMBANGAN INSTRUMEN SIKAP TOLERANSI DALAM PEMBELAJARAN TEMATIK KELAS 5 SD Kurikulumi2013 di Indonesia dengan Standar Kompetensi Lulusan Bhinneka Tunggal Ika yang dengan arti berbeda-beda tetapi tetap. 3(3). https://doi.org/10.31604/ptk.v3i1.41-52

Nugroho, A. S., \& Mawardi, M. (2021). Pengembangan Instrumen Penilaian Sikap Tanggungjawab dalam Pembelajaran Tematik di Sekolah Dasar. Jurnal Basicedu, 5(2), 808-817. https://doi.org/10.31004/basicedu.v5i2.825

Purwanto. (2010). Instrumen Penelitian Sosial Dan Pendidikan. Pustaka Pelajar.

Samsul, P., \& Mutmainnah, M. (2018). Pengembangan Instrumen Penilaian Autentik pada Pembelajaran dengan Pendekatan Scientific. Edumaspul - Jurnal Pendidikan. https://doi.org/10.33487/edumaspul.v2i1.20

Setiawan, R. A. (2020). Lembar Kegiatan Literasi Saintifik untuk Pembelajaran Jarak Jauh Topik Penyakit Cronavirus 2019 (Covid-19). Edukatif: Jurnal Ilmu Pendidikan, 2(1), 28-37.

Setiawan, H., \& Tumardi, T. (2019). Pengembangan Instrumen Asesmen Kompetensi pada Ranah Afektif di Sekolah Dasar. Musamus Journal of Primary Education. https://doi.org/10.35724/musjpe.v2i1.1944

Sugiyono. (2009). Metode Penelitian Pendidikan. Alfabeta.

Sukmadinata. (2016). Metode Penelitian Pendidikan. Remaja Rosdakarya. 
648 Pengembangan Instrumen Penilaian Sikap Gotong Royong dalam Pembelajaran Tematik di Sekolah Dasar - Dian Kurniawati, Mawardi

DOI: https://doi.org/10.31004/edukatif.v3i3.387

Sriyono, S. (2019). Pengembangan Instrumen Penilaian Sikap Sosial Berbasis Proyek Pada Pembelajaran Fisika Sma. Jurnal Pendidikan Surya Edukasi (JPSE), 5(2), 159-168. https://doi.org/10.37729/jpse.v5i2.6081

Umami, M. (2018). Penilaian Autentik Pembelajaran Pendidikan Agama Islam dan Budi Pekerti dalam Kurikulum 2013. Jurnal Kependidikan, 6(2), 222-232. https://doi.org/10.24090/jk.v6i2.2259 